\title{
Feasibility Analysis of Contents of Module Impulse and Momentum to Improve Student Math Skills Verbal Representation of Figures (R- VMGG)
}

\author{
I Ketut Mahardika1* ${ }^{*}$ I Wayan Sugiartana², Aris Doyan³ \\ 1 Study Program of Doctoral Science Education, FKIP, University of Jember, Jember, East Java, Indonesia \\ 2SMPN Tegallalang Gianyar, Bali Island, Bali, Indonesia \\ ${ }^{3}$ Physical Education Study Program, FKIP,University of Mataram, West Nusa Tenggara, Indonesia \\ ${ }^{3}$ Master Science Education Study Program, Postgraduate, University of Mataram, West Nusa Tenggara, Indonesia
}

DOI: $\underline{10.29303 / \text { jossed.v2i1.524 }}$

\section{Article Info}

Received :

Revised :

Accepted:

\begin{abstract}
Abstrak: This article reports on the results of the development of impulse and momentum modules to improve the Verbal, Mathematical, Image and Graphic Representation (RVMGG) abilities of high school students in Besuki Raya. The research objective was to describe the feasibility level of the content, the impulse module and momentum of the development results. The trials were carried out on small samples and large samples, after validation by experts. The large sample trial is carried out after completing the small sample trial which is carried out in stages from all learning activities with the impulse and momentum module. Trials with small samples and large samples were carried out to investigate the impulse and momentum module drafts of the development results in improving the R-VMGG abilities of SMAN students in Besuki Raya. Respondents in the small sample trial were 30 high school students, while the respondents in the large sample trial were 150 high school students. The results showed that the feasibility level of the contents of the developed modules reached a high category.
\end{abstract}

Keyword: Feasibility of Content; Verbal Representation; Mathematics; Pictures; Graphics (R-VMGG)

Citation: Mahardika, I., Sugiartana, I., \& Doyan, A. (2021). Feasibility Analysis of Contents of Module Impulse and Momentum to Improve Student Math Skills Verbal Representation of Figures (R-VMGG). Journal of Science and Science Education, 2(1), 47-51. doi:https://doi.org/10.29303/jossed.v2i1.524

\section{Introduction}

Mastery of physics concepts correctly can be done through mastery of physics in a multirepresentation. Physical representation is a clear and detailed presentation of physical phenomena. Waldrip et al., (2006) explains that multirepresentation of concept mastery is the mastery of a knowledge concept in images, in the form of graphs or diagrams. Dabutar (2007) states that multi-representation is the mastery of a concept of knowledge verbally, pictures, and graphics. Mahardika (2012) further explains that mastery of physics concepts in a multirepresentation is mastery of physics concepts by combining representation formats, namely verbal, image, mathematical, and graphic formats. Based on the above opinions, correct mastery of physics can be done through verbal representations, image representations, mathematical representations, and through graphical representations. By involving multiple representations it can provide a rich context for students to understand a physics concept correctly and free from misconceptions.

Related to the above, the physics module as one of the physics learning media will greatly help students 
and other users if it is presented through verbal, image, mathematical, and graphic formats. Presentation of concepts in the module is also important to pay attention to the principles in classroom learning strategies. The National Science Education Standard states that teaching strategies will be successful if they are presented with real examples, namely how to use teaching methods to teach physics materials in the right context (NRC, 1996). Alwasilah (2005) argues that teaching materials (modules) have a very important role in the education system. The same thing was also stated by Hayati (2001), that the role of modules in the educational process occupies a very strategic position and helps determine the achievement of educational goals. Modules are instrumental input along with curriculum, instructors, media, and evaluation. The quality of educational processes and outcomes is influenced, among others, by the modules used, which meet the aspects of legibility, content feasibility, and graphics (Rustaman, 1995), as well as illustrations (Belawati, 2006). Meanwhile, the Center for Educational Technology Development (2008) mentions the functions of the module as: a) guidelines for lecturers, teachers, tutors, b) guidelines for students (students), and c) tools for evaluating the achievement of learning outcomes. Therefore, a module that describes clear and detailed physical phenomena with balanced forms of verbal, picture, mathematical and graphic representations, accompanied by examples of questions that are also presented in verbal, picture, mathematical, and graphical representation formats are very important. required in particular by students and other module users.

Representation is one of the best and currently developing techniques to instill an understanding of the concept of physics. Representations can also show objects and their natural behavior. The difficulty caused by the large number of involved mental images can be overcome through representation. Physical phenomena can be explained by R-VMGG, therefore multirepresentations such as demonstration learning methods, experiments and other learning methods can help overcome difficulties in assessing physics concepts which require the involvement of physical knowledge and mathematical logic (Dahar 1989; Van den Berg , 1991). Multirepresentation can also be used to analyze a model in assessing physics concepts correctly. Related to this, Bao and Radish., (2006) argued that model analysis to apply qualitative research in building a quantitative representation framework can be obtained from the test results of the concept of force and motion of force. Likewise, motivation in assessing low physics concepts can be increased through representation (Kohl and Finkelstein., 2006; Laili et al., 2015).
Exposure to the module as above is predicted to improve students' ability to understand physics concepts, especially the concepts of impulses and momentum by means of R-VMGG. Thus, it is necessary to develop an Impulse and Momentum module that can help improve Verbal, Mathematical, Image and Graphic Representation (R-VMGG) abilities for high school students in Besuki Raya.

The purpose of this study is to develop Impulse and Momentum modules that can be used to improve the R-VMGG abilities of SMAN students in Besuki Raya. The specific purpose which is informed through this article is to assess the feasibility level of the content of the Impulse and Momentum module in improving the R-VMGG abilities of SMAN students in Besuki Raya.

\section{Method}

The subjects in this study were the Impulse and Momentum Module (MIM) as a result of the development. Respondents of this study were 150 students of SMAN in Besuki Raya. The methods for collecting data are: essay test, gaps test, questionnaire, observation, interview, and documents.

This research steps can be summarized in a research flowchart as can be seen in figure 1.

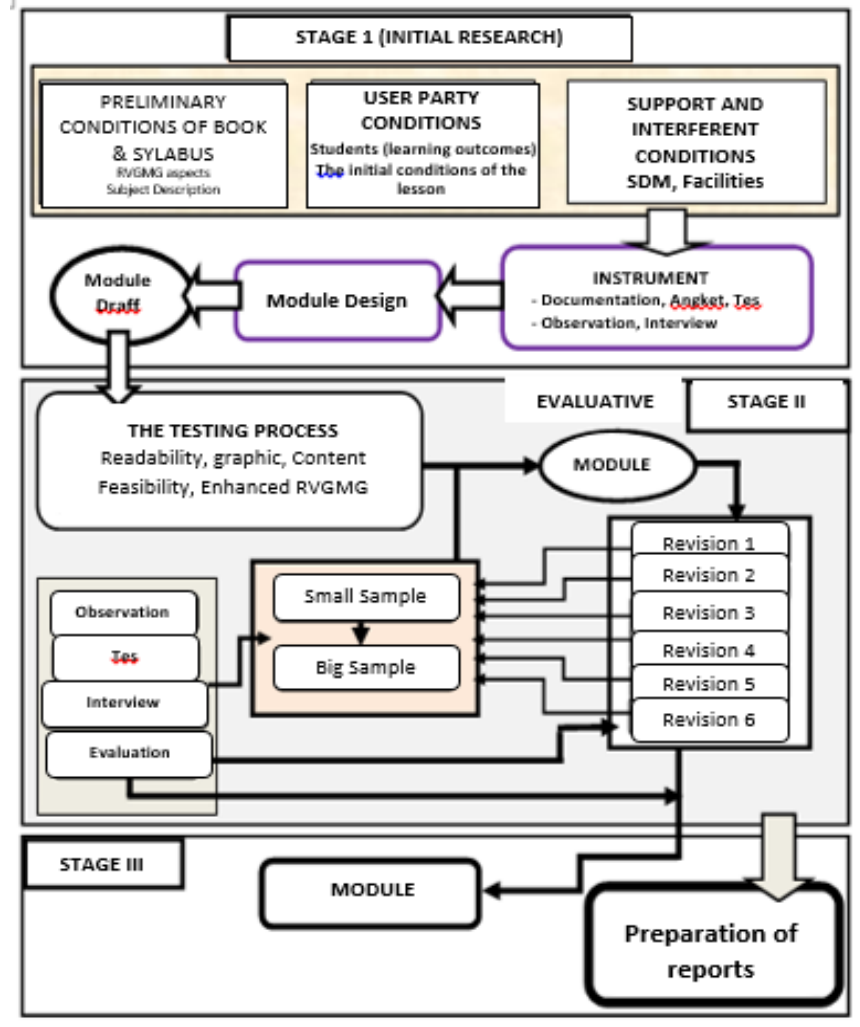

Figure 1. Steps for module design and research procedures The feasibility study of the module content refers to the essay test results as the main data. The pre test scores and post test scores generated by the students were then analyzed using the N-gain formula (Hake, 
1999; Meltzer, 2002; Coletta, 2007; IK. Mahardika, 2012). And to see the increase in learning outcomes used the criteria for scoring categories, namely: $\mathrm{N}$-gain $\geq 0.7$ (high category); $0.3<\mathrm{N}$-gain $<0.7$ (moderate); and Ngain $\leq 0.3$ (low). Multiply the content of the module is also studied through supporting data from the results of questionnaire data, observation and interviews.

The module readability study uses the results of the gaps test which is carried out by eliminating parts of words and formulas of a concept in the text so that they become gaps. Filling in the gaps to bring up reading activity naturally and normally. The laying of word parts and formulas is done randomly based on the characters of the Impulse and Momentum module. The readability analysis of the module uses the Readability Level, which is the score obtained by students divided by the maximum score multiplied by $100 \%$ (Suhadi, 1996). The readability category was divided into three categories, namely: RC > 57\% (high); $44 \% \leq \mathrm{RC} \leq 57 \%$ (moderate), and RC $<44 \%$ (low).

The module graphical study uses a score of data from the results of research on the responses of subject teachers and expert validators to the module which contains the graphic aspects of a module, such as: use of fonts, type and size of letters, layout, illustrations, pictures, photos, symbols, formulas, and design of appearance. Analysis of the results of teacher and validator responses is used as the basis for revising the module draft in subsequent learning activities. The module's graphic category is also divided into 3 categories, namely: high, medium, and low.

\section{Result and Discussion}

\section{Feasibility Module Content}

The illustration of the results of the increase in the ability of R-VMGG in the Impulse and Momentum module is reflected in examples of answers from students to the post-test questions they have done as follows; The water comes out of the hose with a discharge of $3.0 \mathrm{~kg} . \mathrm{s}-1$ and a rate of $20 \mathrm{~m} . \mathrm{s}-1$, and is directed at the side of the car, which stops its forward motion, Figure 2. That is, we ignore the backward splash. a) Draw the required vector quantities in Figure 2 ; b) How much force does the water exert on the car? Explain your answer verbally as well as mathematically; and c) illustrate the graph of the relationship between the force exerted by water on the car and the time of collision.

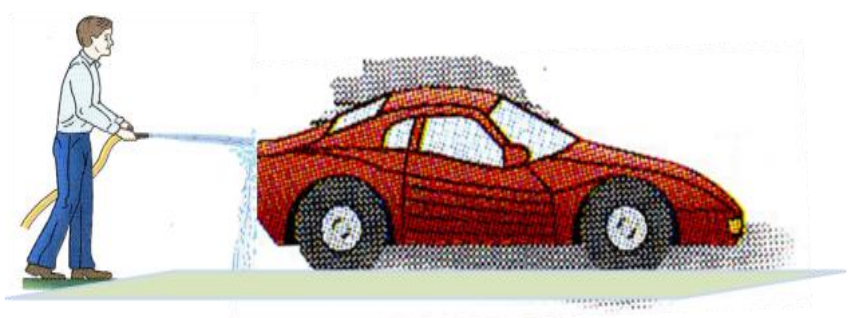

Figure 2. Water is sprayed on the car and immediately stopped by the car

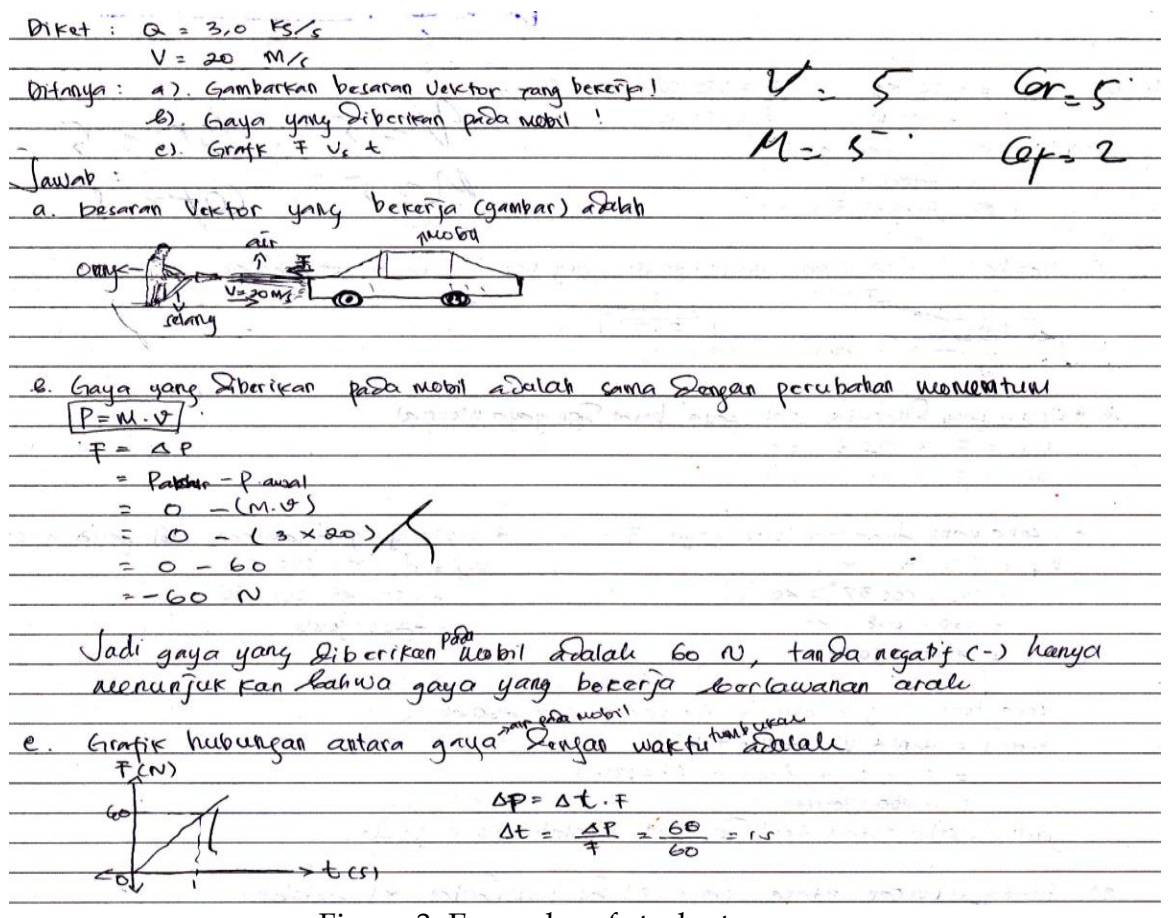

Figure 3. Examples of student answers 
The highest score for each representation is determined to be five for the perfect answer, and zero for the lowest if the student does not give an answer. Each representation has determined its assessment criteria.
The next step after assessing with the question answer grid, the results of the pre-test and post-test the students recap the average pre-test, post-test, and $\mathrm{N}$ gain R-VMGG scores as shown in Table 1.

Table 1. Average pre-test, post-test scores, and the Momentum and Impulse Modules

\begin{tabular}{|c|c|c|c|c|c|c|}
\hline No & Representation & Average Pre test & Average Pos test & Score Maximum & N-gain & Decribe \\
\hline 1. & Verbal & 10.0 & 15.50 & 18.00 & 0.69 & Moderate \\
\hline 2. & Image & 7.30 & 14.20 & 17.00 & 0.71 & High \\
\hline 3. & Mathematical & 8.60 & 17.00 & 20.00 & 0.74 & High \\
\hline & Graphic & 5.40 & 11.90 & 14.50 & 0.71 & High \\
\hline Sum & RVMGG & 31.20 & 58.60 & 69.50 & 0.72 & High \\
\hline Ave & age RVMGG & 7.80 & 14.70 & 17.40 & 0.72 & High \\
\hline
\end{tabular}

From Table 1, it shows an increase in students' understanding of physics concepts through verbal representation with a value of $\mathrm{Ng}=0.69$ (moderate category). Meanwhile, for understanding the concept of physics through image, mathematical, and graphic representations, the $\mathrm{Ng}$ value is above 0.70 (high category). Meanwhile, the number of R-VMGG is a multi-representation which is the result of student learning in the cognitive domain with a value of $\mathrm{Ng}=$ 0.72 (high category). These results prove that the Impulse and Momentum module has very good content feasibility, which means it does not spread misconceptions. The results of this study are also in accordance with the statement of Belawati (2006) which states that the appropriateness of the content of teaching materials is very important to pay attention to so that the teaching materials do not spread concept errors or "misconceptions". Concept errors will be brought by learners to the next level of education or into their lives (IK. Mahardika, 2012; Prasti et al., 2014).

\section{Conclusion}

The Impulse and Momentum Module has been successfully developed to improve the R-VMGG abilities of SMAN students in Besuki Raya. After being tested and assessed for the development results module, the level of its content feasibility is verbal, mathematics, pictures, and graphics, with a high average category. The conclusion that can be drawn from the results of this study, that the Impulse and Momentum Module developed, has a high level of content feasibility (valid).

\section{References}

Alwasilah, A.C. (2005). Menaksir Buku Ajar, Pikiran Rakyat [Online], Retrieved from: http://www.pikiranrakyat.com/cetak/2005/050 5/26/cakra-wala/index.htm. [19 Nopember 2009].
Bao, L. \& Redish, E.F. (2006). Model analysis: Representing and assessing the dynamics of student learning. Phys. Rev. ST: Phys. Educ. Res.2, 010103. doi:10.1103/PhysRevSTPER.2.010103

Belawati, T. (2006). Pengembangan Bahan Ajar, Jakarta: Universitas Terbuka. [Indonesan]

Center for Educational Technology Development. (2008). Panduan Pengembangan Bahan Ajar. Jakarta: Dirjen Dikdasmen. [Indonesian]

Coletta, V.P. (2007). Interpreting force concept inventory scores: Normalized gain and SAT scores. [online]. Retrieved from: http://www.prstper.aps.org/PRSTPER/v3/i1/e 010106/ [Indonesia].

Dabutar, J. (2007). Strategi Pembelajaran Quantum Teaching dan Quantum Learning. [Online] Retrieved from: butar_lbt@yahoo.co.id. [Akses: 10 Maret 2010]. [Indonesan]

Dahar, R.W. (1989). Teori-teori Belajar. Jakarta: Erlangga.

Hake, R.R. (1999). Analyzing Change/Gain Scores. [online]. Retrieved from: http://www.physics.indiana.edu/sdi/Analyzin gChange-Gain.pdf . [5 Pebruari 2011].

Hayati, S. (2001). Pengembangan Bahan Ajar Berorientasi Kehidupan dan Alam Pekerjaan. Bandung: Lembaga Penelitian Universitas Pendidikan Indonesia. [Indonesian]

Kohl, P.B. \& Finkelstein, N.D. (2006). Effect of instructional environment on physics students' representational skills. Phys. Rev. ST: Phys. Educ. Res.2, 010102.

Laili, Y., Mahardika, I., \& Ghani, A. (2015). Pengaruh Model Children Learning In Science (CLIS) Disertai LKS Berbasis Multirepresentasi Terhadap Aktivitas Belajar Siswa Dan Hasil Belajar Siswa Dalam Pembelajaran Fisika Di SMA Kabupaten Jember. Jurnal Pembelajaran Fisika, 4(2). Retrieved from https://jurnal.unej.ac.id/index.php/JPF/article /view/2163 [Indonesan] 
Mahardika, K., (2012). Representasi Mekanika dalam Pembahasan Suatu teori dan hasil penelitian pengembangan BAM. UPT Penerbitan UNEJ. Jember. [Indonesan]

Meltzer, David, E. (2002). The relationship between Mathematics preparation and conceptual learning gain in Physics: A possible hidden variable in diagnostic pretest scores. American Journal Physics. 70 (2), 1259-1267. Doi: https://doi.org/10.1119/1.1514215

National Research Council (NRC). (1996). National Science Education Standards. Washington, DC: National Academy Press.

Prasti, W., IK Mahardika, \& Alex, H. (2014). Penerapan Model Pembelajaran LC Berbasis Multirepresentasi terhadap Kemampuan RVMG2 di SMP. Jurnal Pembelajaran Fisika, 2(4). [Indonesan]

Rustaman, N. (1995). Proposal Pengkajian dan Penilaian Buku Pelajaran IPA Biologi SLTP. Jakarta: Direktorat Pendidikan Menengah UmumDepdikbud. [Indonesan]

Van den Berg, (Eds) (1991). Miskonsepsi Fisika dan Remediasinya. Salatiga: Universitas Kristen Satyawacana. [Indonesan]

Waldrip, B., Prain, V., \& Carolan, J. (2006). “Learning Junior Secondary Science through Multi-Modal Representations". Electronic Journal of Science Education.11, (1), 88-107. 